\title{
BISAKAH MEMPEROLEH STATISTIK INDEKS HARGA KONSUMEN TINGKAT PROVINSI DI INDONESIA DENGAN KETELITIAN YANG LEBIH BAIK?
}

\author{
(Can Provincial Level Consumer Price Indices Statistics in Indonesia be Obtained with \\ Better Accuracy?)
}

\author{
Andi Okta Fengki ${ }^{1}$, Khairil Anwar Notodiputro ${ }^{2}$, Kusman Sadik ${ }^{2}$ \\ ${ }^{1}$ Badan Pusat Statistik Provinsi Bengkulu, Badan Pusat Statistik \\ ${ }^{2}$ Departemen Statistika, Institut Pertanian Bogor \\ Taman Griya Kencana, Kota Bogor \\ E-mail: andiokta@bps.go.id dan andi geb10@apps.ipb.ac.id
}

\begin{abstract}
ABSTRAK
Statistik indeks harga konsumen (IHK) atau consumer price index (CPI) juga dibutuhkan pada tingkat provinsi di era desentralisasi saat ini. Ketika IHK ingin diduga pada tingkat provinsi, permasalahan ukuran contoh kecil (small area) muncul karena survei untuk menghasilkan IHK ini di Indonesia dirancang untuk tingkat nasional. Akan tetapi, informasi dari statistik IHK 82 kota dapat membantu untuk menduga IHK provinsi. Metode pendugaan area kecil atau small area estimation (SAE) dapat diterapkan sebagai solusi untuk meningkatkan ketelitian hasil pendugaan langsung. Pada penelitian ini IHK provinsi diduga menggunakan model Fay-Herriot (FH). Hasilnya menunjukan bahwa model FH dapat menghasilkan statistik IHK provinsi dengan ketelitian yang lebih baik dari pendugaan langsung. Hal ini ditunjukan dengan nilai average relative root mean square error (ARRMSE) penduga FH IHK provinsi yang lebih kecil dari penduga langsungnya.
\end{abstract}

Kata kunci: indeks harga konsumen, IHK provinsi, pendugaan area kecil, model Fay-Herriot

\section{ABSTRACT}

Consumer price indices statistics (CPI) is also needed at the provincial level in the current era of decentralization. When the CPI wants to be estimated at the provincial level, the problem of small sample size arises because the survey to produce this CPI in Indonesia is designed at the national level. However, information from the 82 cities CPI statistics can help to estimate the provincial CPI. The small area estimation (SAE) method can be applied as a solution to improve the accuracy of direct estimation results. In this study, the provincial CPI was estimated using the Fay-Herriot (FH) model. The results show that the FH model can produce provincial CPI statistics with better accuracy than direct estimation. This is indicated by the value of the average relative root mean square error (ARRMSE) of the provincial CPI FH estimator is smaller than the direct estimator.

Keywords: consumer price index, provincial CPI, small area estimation, Fay-Herriot model

\section{PENDAHULUAN}

Statistik indeks harga konsumen (IHK) atau consumer price index (CPI) adalah salah satu indikator ekonomi penting yang digunakan luas oleh pemerintah, bank sentral, dan institusi keuangan dalam menginvestigasi prilaku ekonomi (Shang et al. 2018). Penggunaan statistik IHK yang luas pada era desentralisasi saat ini membuat statistik IHK dibutuhkan di tingkat daerah karena masing-masing daerah membutuhkan statistik untuk perencanaan dan evaluasi pembangunan yang lebih sesuai. Pelaku usaha juga membutuhkannya dalam menetapkan keputusan ekonomi, sehingga keputusan yang diambil lebih tepat sasaran. Selain itu, statistik resmi yang dikeluarkan Badan Pusat Statistik (BPS) kebanyakan juga tersedia pada tingkat daerah terutama tingkat provinsi. Dengan demikian, statistik IHK tingkat provinsi penting untuk disediakan.

Permasalahan ukuran contoh kecil muncul ketika ingin menduga IHK tingkat provinsi, karena survei yang dilakukan BPS kebanyakan dirancang untuk tingkat nasional, termasuk survei untuk memperoleh statistik IHK. Survei tersebut adalah survei biaya hidup (SBH) tahun 2012 dan survei harga konsumen (SHK) yang hanya dilakukan BPS di 82 kota di Indonesia sejak tahun 2014 (BPS 
2018). Ukuran contoh yang kecil menyebabkan statistik hasil pendugaan memiliki ketelitian yang kurang baik.

Namun, statistik IHK hasil survei di 82 kota dapat dijadikan sumber informasi untuk dapat menduga IHK provinsi. Jika diasumsikan 514 ibukota kabupaten/kota di Indonesia sebagai populasi kota IHK, maka 82 kota yang dipilih dan tersebar dimasing-masing provinsi disebut kota contoh IHK. Kota contoh tersebut di beberapa provinsi terindikasi berukuran kecil, terlihat dari proporsinya terhadap banyaknya kota di masing-masing provinsi yang lebih kecil dari proporsi kota contoh nasional. Bahkan, ada beberapa provinsi hanya memiliki satu kota contoh saja.

Metode pendugaan area kecil atau small area estimation (SAE) dapat diterapkan sebagai solusi untuk meningkatkan ketelitian hasil dugaan dibandingkan dengan hanya menggunakan metode pendugaan langsung pada area kecil (Rao \& Molina 2015). Metode SAE bersifat meminjam kekuatan atau borrowing strength dari informasi tambahan dari luar survei, hasil sensus, atau hasil pencatatan administrasi.

Kajian penerapan SAE pada IHK regional telah dilakukan untuk membangun keranjang komoditas dan bobot IHK regional (Wurz et al. 2017). Penelitian ini menggunakan model Fay-Herriot untuk meningkatkan hasil pendugaan langsung dengan menambahkan informasi sensus sebagai peubah penyerta. Penelitain lanjutan IHK regional juga dilakukan oleh Dawber et al. (2019).

Di Indonesia, SAE kebanyakan diterapkan untuk menduga indikator kemiskinan (Pusponegoro \& Rachmawati 2018; Sundara et al. 2016; Wulansari et al. 2014) dan pengeluaran perkapita (Ubaidillah et al. 2019; Nuryadin et al. 2018; Sriliana et al. 2017). Oleh karena itu, penelitian ini menyumbangkan pemikiran untuk menerapkan SAE pada IHK. Tujuan penelitian ini adalah untuk memperoleh statistik IHK tingkat provinsi dengan ketelitian yang lebih baik dengan menggunakan metode SAE.

\section{METODE}

\section{Data}

Peubah respon atau peubah yang menjadi fokus penelitian adalah IHK provinsi Januari 2018. Peubah respon diperoleh dari SHK yang dihasilkan oleh BPS. Karena SHK dilaksanakan setiap bulan, sehingga statistik IHK yang tersedia umumnya disajikan per bulan. Oleh karena itu, peubah penyerta yang dipilih adalah peubah penyerta yang tersedia setiap bulan dan diyakini berpengaruh terhadap IHK.

Suatu faktor yang mempengaruhi inflasi dapat juga mempengaruhi IHK karena inflasi merupakan laju pertumbuhan dari IHK, artinya hubungan IHK dan inflasi berbanding lurus. Beberapa faktor yang dapat mempengaruhi inflasi adalah jumlah uang yang beredar (Bala et al. 2017; Kalalo et al. 2016; Lim \& Sek 2015), harga bahan bakar minyak (Bala et al. 2017; Kalalo et al. 2016; Yoshizaki \& Haomori 2014), dan nilai tukar mata uang atau harga valuta asing (Islam et al. 2017; Bala et al. 2017; Kalalo et al. 2016; Saputra \& Nugroho 2014). Oleh karena itu, peubah penyerta yang dipilih terdiri dari tiga kelompok yaitu jumlah uang yang beredar (JUB), harga bahan bakar minyak (HBBM), rata-rata harga valuta asing (RHVA).

Tabel 1. memperlihatkan keterangan lebih rinci peubah yang digunakan. Peubah penyerta kelompok JUB, yaitu pinjaman masyarakat (PM) dan kredit usaha mikro kecil menengah (KUMKM), dan kelompok HBBM, yaitu pertalite, pertamax, pertamax turbo (PT), pertamax racing (PR), dexlite, dan pertamina dex (PD). Kemudian, peubah penyerta kelompok RHVA, yaitu harga beli Dollar Amerika Serikat (HBUSD), harga jual Dollar Amerika Serikat (HJUSD), harga beli Dollar Australia (HBAUD), harga jual Dollar Australia (HJAUD). Peubah penyerta kelompok JUB dan HBBM adalah data Januari 2018. Sedangkan, peubah penyerta kelompok RHVA adalah data Januari 2017. RHVA Januari 2017 digunakan sebagai pendekatan karena data RHVA Januari 2018 belum tersedia.

Peubah penyerta dipilih adalah hasil pencatatan administrasi untuk meminimalisir kemungkinan terjadinya kesalahan pengukurannya. Peubah penyerta kelompok JUB diperoleh dari situs Bank Indonesia (BI), yaitu https://www.bi.go.id/. Sedangkan, peubah penyerta kelompok HBBM diperoleh dari situs Pertambangan Minyak dan Gas Bumi Negara (Pertamina), yaitu https://www.pertamina.com/. Situs BPS, https://bps.go.id. juga menyediakan peubah penyerta kelompok RHVA selain peubah respon yang digunakan. 
Tabel 1. Peubah penelitian.

\begin{tabular}{lll}
\hline \multicolumn{1}{c}{ Peubah } & Satuan & \multicolumn{1}{c}{ Sumber } \\
\hline $\begin{array}{l}\text { IHK }(Y) \\
\text { JUB }\end{array}$ & Persen & BPS, https://bps.go.id. \\
PM $\left(x_{1}\right)$ & Triliun rupiah & \\
KUMKM $\left(x_{2}\right)$ & Triliun rupiah & Pertamina, https://www.bi.go.id/ \\
HBBM & Rupiah & \\
Pertamax $\left(x_{3}\right)$ & Rupiah & \\
Pertalite $\left(x_{4}\right)$ & Rupiah & \\
PT $\left(x_{5}\right)$ & Rupiah & \\
PR $\left(x_{6}\right)$ & Rupiah & \\
Dexlite $\left(x_{7}\right)$ & Rupiah & \\
PD $\left(x_{8}\right)$ & & BPS, https://bps.go.id. \\
RHVA & Rupiah & \\
HBUSD $\left(x_{9}\right)$ & Rupiah & \\
HJUSD $\left(x_{10}\right)$ & Rupiah & \\
HBAUD $\left(x_{11}\right)$ & Rupiah & \\
HJAUD $\left(x_{12}\right)$ & &
\end{tabular}

\section{Pendugaan Langsung}

Pendugaan langsung atau direct estimation (DE) adalah suatu metode pendugaan pada suatu area berdasarkan informasi data contoh dari area tersebut (Pusponegoro \& Rachmawati 2018). Pada $\mathrm{DE}$, parameter populasi diduga hanya dengan menggunakan data hasil surveinya. Degan kata lain, DE menduga parameter populasi sesuai dengan desain survei yang digunakan. Misalnya, rataan populasi diduga dengan rataan contoh simple random sampling (SRS) jika data diperoleh dari survei dengan desain penarikan contoh SRS.

Desain penarikanan contoh utama dalam statistika adalah SRS. Akan tetapi, SRS sering dimodifikasi karena kesulitan untuk diterapkan di dalam prakteknya. Beberapa data kadang-kadang diasumsikan diperoleh dari desain penarikan contoh SRS untuk memudahkan pendugaan parameternya.

Andaikan pemilihan kota IHK diasumsikan menggunakan metode SRS dan harga di wilayah perkotaan (urban) dan pedesaan (rural) suatu kabupaten/kota relatif sama, maka rataan IHK provinsi diduga dengan menggunakan statistik desain penarikan contoh SRS. Rumus penduga tak bias untuk menduga IHK provinsi ke- $i, Y_{i}$ pada desain penarikan contoh SRS adalah

$$
\hat{Y}_{i}^{S R S}=\frac{1}{n_{i}} \sum_{j \in S_{i}} y_{i j}
$$

dengan $\hat{Y}_{i}^{S R S}$ adalah statistik IHK provinsi ke- $i$ metode SRS, $n_{i}$ banyaknya kota contoh pada provinsi ke- $i, y_{i j}$ IHK kota contoh ke- $j$ pada provinsi ke- $i, S_{i}$ adalah indeks untuk unit di dalam contoh provinsi ke- $i$.

Mean Square Error (MSE) digunakan untuk mengukur kebaikan hasil pendugaan. Jika penduga ragam IHK kota di provinsi ke- $i, s_{i}^{2}$, banyaknya kota contoh pada provinsi ke- $i, n_{i}$, dan banyaknya populasi kota pada provinsi ke- $i, N_{i}$, diketahui maka MSE penduga langsung SRS dapat diduga dengan rumus: 


$$
\operatorname{MSE}\left(\hat{Y}_{i}^{S R S}\right)=\frac{s_{i}^{2}}{n_{i}}\left(1-\frac{n_{i}}{N_{i}}\right)
$$

Pada SHK, kota contoh dipilih secara proporsif dengan kriteria tertentu sehingga peluang terpilihnya kota tidak sama. Penarikan contoh kota tersebut berdasarkan pada tingkat pembangunan di bidang perekonomian yang relatif pesat apabila dibandingkan dengan kota-kota lainnya (BPS 2013). Masing-masing kota diberikan bobot tertentu. Dengan demikian, rataan IHK provinsi diduga dengan menggunakan kaidah rataan terboboti, sesuai dengan prinsip bahwa IHK untuk tingkat yang lebih tinggi adalah rataan terboboti dari IHK tingkat di bawahnya (ONS 2010). Pada penelitian ini, statistik IHK tingkat provinsi yang diperoleh dengan metode ini disebut dengan metode weighted proporsive sampling (WPS) karena kota dipilih secara proporsif dan diberi bobot. Statistik WPS dihitung dengan rumus sebagai berikut:

$$
\hat{Y}_{i}^{W P S}=\frac{1}{\sum_{j=1}^{n_{i}} w_{(0) i j}} \sum_{j=1}^{n_{i}} w_{(0) i j} y_{i j}
$$

dengan $\hat{Y}_{i}^{W P S}$ adalah statistik IHK provinsi ke- $i$ metode WPS, $n_{i}$ banyaknya kota contoh pada provinsi ke- $i, y_{i j}$ IHK kota contoh ke- $j$ pada provinsi ke- $i, w_{(0) i j}$ adalah bobot untuk kota contoh ke- $j$ pada provinsi ke- $i$.

Kemudian, MSE penduga WPS juga dihitung untuk mengukur kebaikan hasil pendugaannya. MSE penduga WPS dapat dihitung dengan rumus sebagai berikut:

$$
\operatorname{MSE}\left(\hat{Y}_{i}^{W P S}\right)=\frac{s_{i}^{2}}{\left(\sum_{j=1}^{n_{i}} w_{0 i j}\right)^{2}}\left(\sum_{j=1}^{n_{i}} w_{0 i j}{ }^{2}\right)
$$

\section{Model Fay-Herriot}

Model Fay-Herriot merupakan model dasar SAE tingkat area karena peubah penyerta hanya tersedia pada level area kecil dan peubah respon yang diamati berupa rata-rata karekteristik area kecil. Model ini pertama kali dikembangkan oleh Fay dan Herriot (1979) sebagai SAE berbasis model. Pada model Fay-Herriot, jika peubah penyerta, $\mathbf{x}_{\mathbf{i}}=\left(x_{1 i}, x_{2 i}, \ldots, x_{p i}\right)^{T}$ tersedia di masing-masing provinsi dan diasumsikan terhubung dengan IHK provinsi ke- $i, Y_{i}$, maka $Y_{i}$, dapat dituliskan dalam model linier

$$
Y_{i}=\mathbf{x}_{\mathbf{i}}^{\mathbf{T}} \boldsymbol{\beta}+v_{i}
$$

dengan $i=1,2, \ldots, m$, nilai $m$ adalah banyaknya provinsi yang memiliki contoh, $\boldsymbol{\beta}=\left(\beta_{1}, \beta_{2}, \ldots, \beta_{p}\right)^{T}$ adalah vektor koefisien regresi berukuran $p \times 1$, dan $v_{i}$ adalah pengaruh acak spesifik provinsi ke$i$ diasumsikan berdistribusi saling bebas dan dan identik, dinotasikan dengan $v_{i}{ }^{i i d}\left(0, \sigma_{v}^{2}\right)$.

Jika penduga langsung IHK provinsi $\hat{Y}_{i}^{D E}$ tersedia untuk meduga $Y_{i}$, dengan model (5), maka penduga langsung $\hat{Y}_{i}^{D E}$ tersebut dimodelkan dengan

$$
\hat{Y}_{i}^{D E}=Y_{i}+e_{i}
$$

dengan $e_{i} \square\left(0, \sigma_{e}^{2}\right)$ adalah kesalahan penarikan contoh (sampling error). Nilai $v_{i}$ dan $e_{i}$ saling bebas dan biasanya diasumsikan menyebar normal. Jika kedua persamaan (5) dan (6) di atas digabungkan, maka diperoleh 


$$
\hat{Y}_{i}^{D E}=\mathbf{x}_{\mathbf{i}}^{\mathbf{T}} \boldsymbol{\beta}+v_{i}+e_{i}
$$

dengan $i=1, \ldots, m$.

Jika komponen ragam provinsi, $\sigma_{v}^{2}$, tidak diketahui kemudian disubstitusi dengan penduganya, $\hat{\sigma}_{v}^{2}$, maka penduga yang diperoleh disebut empirical best linear unbiased predictor (EBLUP). Penduga EBLUP bagi $Y_{i}$ untuk elemen provinsi teramati adalah

$$
\hat{Y}_{i}^{E B L U P}=\hat{\gamma}_{i} \bar{y}_{i}+\left(1-\hat{\gamma}_{i}\right) \mathbf{x}_{\mathbf{i}}^{\mathbf{T}} \hat{\boldsymbol{\beta}}
$$

dengan $i=1,2, \ldots, m, \bar{y}_{i}$ adalah penduga langsung IHK provinsi ke- $i, \hat{\gamma}_{i}=\hat{\sigma}_{v}^{2} /\left(\hat{\sigma}_{v}^{2}+\hat{\sigma}_{e}^{2}\right)$ dan $\hat{\boldsymbol{\beta}}=\hat{\boldsymbol{\beta}}\left(\hat{\sigma}_{v}^{2}\right)=\left[\sum_{i=1}^{m} x_{i} x_{i}^{T} /\left(\hat{\sigma}_{v}^{2}+\hat{\sigma}_{e}^{2}\right)\right]^{-1}\left[\sum_{i=1}^{m} x_{i} \hat{Y}_{i} /\left(\hat{\sigma}_{v}^{2}+\hat{\sigma}_{e}^{2}\right)\right]$ adalah penduga tak bias linear terbaik bagi $\beta$. Dugaan komponen ragam $\hat{\sigma}_{e}^{2}$ diperoleh dari MSE pendugaan langsung atau $\hat{\sigma}_{e}^{2}=\operatorname{MSE}\left(\hat{Y}_{i}^{D E}\right)$. Metode maximum likelihood (ML) adalah salah satu cara yang dapat digunakan untuk memperoleh dugaan komponen ragam pengaruh acak $\hat{\sigma}_{v}^{2}$. Dugaan $\mathrm{ML} \hat{\sigma}_{v}^{2}$ dihitung dengan persamaan iterasi Newton Raphson atau algoritma Fisher-scoring (Rao dan Molina 2015) sebagai berikut:

$$
\sigma_{v}^{2^{(a+1)}}=\sigma_{v}^{2^{(a)}}+\left[\Im\left(\sigma_{v}^{2^{(a)}}\right)\right]^{-1} s\left(\hat{\beta}^{(a)}, \sigma_{v}^{2^{(a)}}\right)
$$

dengan superskrip $a$ menunjukan iterasi, $a=0,1,2, \ldots, \quad \mathfrak{J}\left(\sigma_{v}^{2^{(a)}}\right)=1 / 2 \sum_{i=1}^{m}\left[1 /\left(\sigma_{v}^{2}+\sigma_{e}^{2}\right)^{2}\right]$, dan $s\left(\hat{\beta}^{(a)}, \sigma_{v}^{2^{(a)}}\right)=-1 / 2 \sum_{i=1}^{m}\left[1 /\left(\sigma_{v}^{2}+\sigma_{e}^{2}\right)\right]+1 / 2 \sum_{i=1}^{m}\left[\left(\hat{Y}_{i}-\mathbf{x}_{\mathbf{i}}^{\mathrm{T}} \boldsymbol{\beta}\right) /\left(\sigma_{v}^{2}+\sigma_{e}^{2}\right)^{2}\right]$. Penduga ML $\hat{\sigma}_{v}^{2}$ diperoleh ketika iterasi sudah konvergen atau $\sigma_{v}^{2^{(a+1)}} \approx \sigma_{v}^{2^{(a)}}$.

Nilai MSE penduga EBLUP digunakan sebagai ukuran kebaikan penduga EBLUP yang dihasilkan. Dugaan MSE penduga EBLUP dihitung dengan rumus:

$$
\operatorname{MSE}\left(\hat{Y}_{i}^{E B L U P}\right) \approx g_{1 i}\left(\hat{\sigma}_{v}^{2}\right)+g_{2 i}\left(\hat{\sigma}_{v}^{2}\right)+2 g_{3 i}\left(\hat{\sigma}_{v}^{2}\right)
$$

dengan $g_{1 i}\left(\hat{\sigma}_{v}^{2}\right)=\hat{\sigma}_{v}^{2} \hat{\sigma}_{e}^{2} /\left(\hat{\sigma}_{v}^{2}+\hat{\sigma}_{e}^{2}\right)=\gamma_{i} \hat{\sigma}_{e}^{2}, g_{2 i}\left(\hat{\sigma}_{v}^{2}\right)=\left(1-\hat{\gamma}_{i}\right)^{2} \mathbf{x}_{\mathbf{i}}^{\mathbf{T}}\left[\sum_{i=1}^{m}\left[\mathbf{x}_{\mathbf{i}} \mathbf{x}_{\mathbf{i}}^{\mathbf{T}} /\left(\hat{\sigma}_{v}^{2}+\hat{\sigma}_{e}^{2}\right)\right]\right]^{-1} \mathbf{x}_{\mathbf{i}}$, dan $g_{3 i}\left(\hat{\sigma}_{v}^{2}\right)=\left(\hat{\sigma}_{e}^{2}\right)^{2}\left(\hat{\sigma}_{v}^{2}+\hat{\sigma}_{e}^{2}\right)^{-3} \bar{V}\left(\hat{\sigma}_{v}^{2}\right)$. Ragam asimptot $\bar{V}\left(\hat{\sigma}_{v}^{2}\right)$ dapat dihitung dengan rumus $\bar{V}\left(\hat{\sigma}_{v}^{2}\right)=2 m^{-2} \sum_{i=1}^{m}\left(\hat{\sigma}_{v}^{2}+\hat{\sigma}_{e}^{2}\right)^{2}$

\section{Tahapan Analisis}

1. Eksplorasi IHK 86 Kota.

2. Pendugaan langsung IHK provinsi.

a. Melakukan pendugaan langsung IHK provinsi dengan metode SRS dan WPS.

b. Menghitung MSE penduga langsung IHK provinsi dengan persamaan (2) dan (4) dan relative root mean square error (RRMSE ) penduga langsungnya dengan persamaan

$$
\operatorname{RRMSE}\left(\hat{Y}_{i}\right)=\frac{\sqrt{M S E\left(\hat{Y}_{i}\right)}}{\hat{Y}_{i}} \times 100 \%
$$


c. Eksplorasi penduga langsung SRS dan WPS.

3. Eksplorasi dan memilih peubah penyerta.

a. Mengecek dan mengimputasi data hilang pada peubah penyerta.

b. Mengecek korelasi peubah respon dan peubah penyerta.

c. Mengecek VIP peubah penyerta.

d. Memilih model terbaik dengan regresi stepwise.

4. Pendugaan IHK provinsi dengan model FH.

a. Memodelkan IHK provinsi dengan model FH.

b. Melakukan pendugaan parameter model FH denga metode EBLUP.

c. Menghitung MSE dan RRMSE penduga FH.

5. Membandingkan RRMSE penduga langsung dengan penduga $\mathrm{FH}$.

6. Menghitung dan membandingkan average relative root mean square error(ARRMSE) penduga langsung dengan penduga $\mathrm{FH}$. Jika $M$ adalah banyaknya provinsi, maka ARRMSE dihitung dengan persamaan

$$
\operatorname{ARRMSE}(\hat{Y})=\frac{\sum_{i=1}^{M} \operatorname{RRMSE}\left(\hat{Y}_{i}\right)}{M} \text {. }
$$

7. Menghitung rataan IHK provinsi dan menduga IHK nasional untuk masing-masing penduga IHK provinsi yang diperoleh.

\section{HASIL DAN PEMBAHASAN}

\section{Eksplorasi IHK Kota}

Statistik IHK 86 kota dieksplorasi terlebih dahulu sebelum digunakan untuk pendugaan langsung. Ini dilakukan untuk melihat pola statistik IHK di 86 kota. Statistik IHK menjadi 86 karena survei sebenarnya dilakukan di 86 kota. Statistik IHK untuk 5 kota di DKI Jakarta digabung menjadi satu karena karakteristiknya diasumsikan sama. Statistik IHK 86 kota cendrung menjulur ke kanan pada histogramnya, artinya rataannya lebih besar dari mediannya. Rataan statistik IHK 86 kota adalah 132.35, sedangkan mediannya 131.53. Dengan kata lain, statistik IHK kota lebih banyak yang lebih kecil dari rataannya.

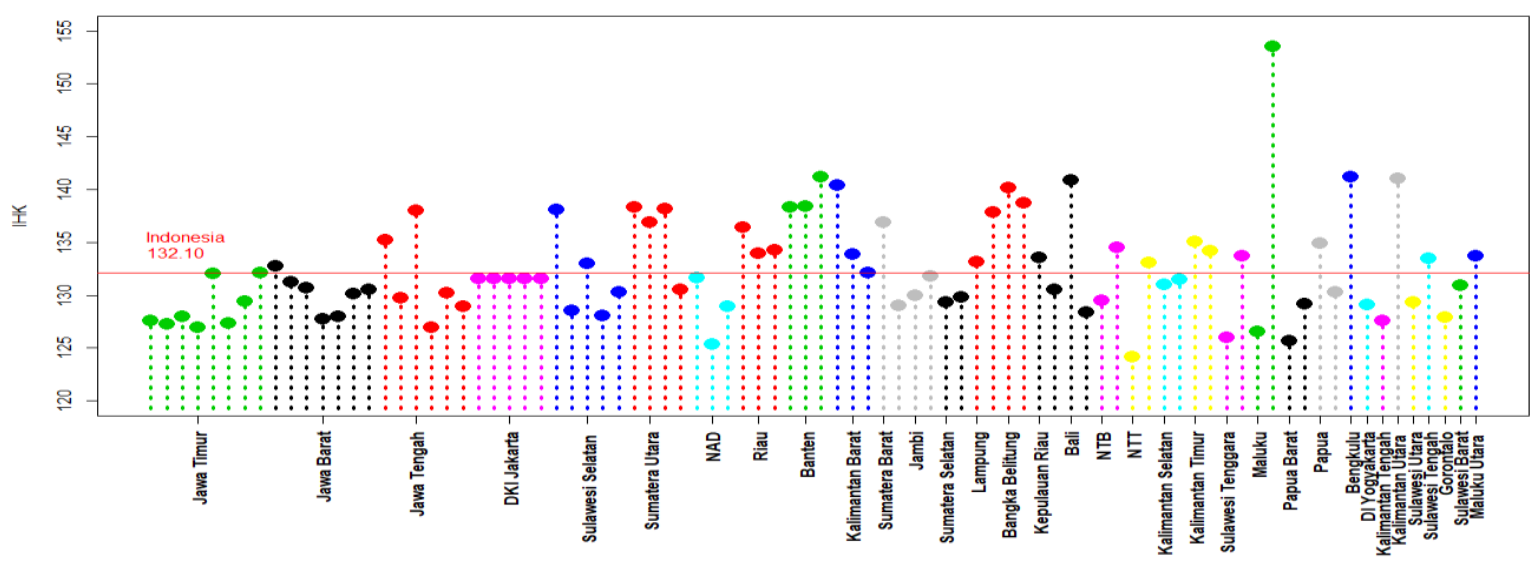

Gambar 1. Statistik IHK 86 kota Januari 2018 menurut provinsi.

Kemudian, statistik IHK 86 kota dieksplorasi lebih lanjut dengan grafik statistik IHK menurut provinsinya. Statistik tersebut diurutkan sesuai banyaknya kota contoh dimasing-masing provinsi. Gambar 1. memperlihatkan bahwa Provinsi Jawa Timur memiliki kota contoh terbanyak yaitu 8 kota. Selain itu, ada 9 provinsi yang hanya memiliki satu kota contoh, yaitu Bengkulu, DI Yogyakarta, Kalimantan Tengah, Kalimantan Utara, Sulawesi Utara, Sulawesi Tengah, Gorontalo, Sulawesi Barat, 
dan Maluku Utara. Gambar 1. juga memperlihatkan bahwa Kota Tual di Provinsi Maluku memiliki nilai statistik IHK tertinggi dan berbeda jauh dengan statistik IHK kota lainnya.

\section{Penduga Langsung IHK Provinsi}

Pendugaan langsung IHK provinsi dilakukan dengan metode SRS dan WPS. Gambar 2. memperlihatkan bahwa penduga langsung SRS terlihat lebih simetris dibanding penduga langsung WPS. Penduga yang lebih simetris menunjukan penduga cederung lebih mendekati normal. Namun, statistik IHK provinsi penduga langsung SRS lebih banyak yang bernilai tinggi.
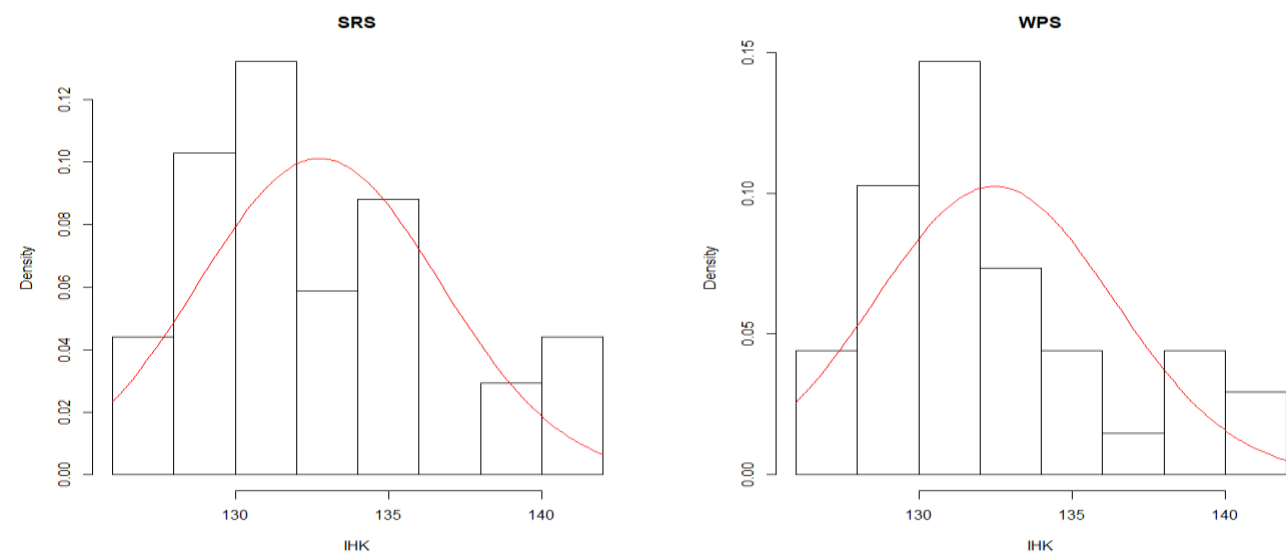

Gambar 2. Histogram penduga langsung IHK provinsi Januari 2018.

Ketelitian penduga langsung IHK provinsi metode SRS lebih baik dibandingkan dengan penduga langsung metode WPS. Nilai RRMSE penduga langsung IHK provinsi metode SRS pada Gambar 3. semuanya lebih kecil dari RRMSE penduga langsung IHK provinsi metode WPS. Pengecualian untuk 9 provinsi yang hanya memiliki satu kota contoh, penduga langsung IHK provinsi di 9 provinsi tersebut sama dengan nilai statistik IHK kota yang terpilih dan tidak dapat ditentukan MSE dan RRMSE-nya. Untuk dapat dilakukan pendugaan IHK provinsi dengan metode $\mathrm{FH}$, MSE tersebut diimputasi dengan nilai nol.

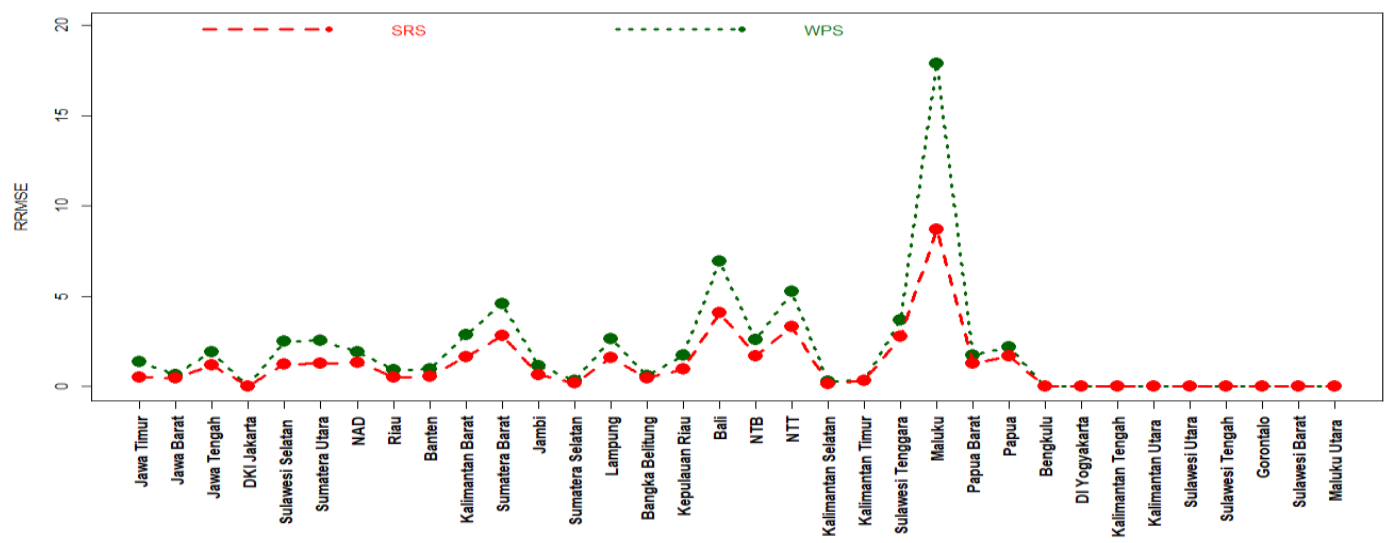

Gambar 3. Grafik RRMSE penduga langsung IHK provinsi Januari 2018.

\section{Imputasi dan Pemilihan Peubah Penyerta}

Peubah penyerta diperiksa terlebih dahulu untuk melihat data hilangnya. Sebanyak 6 peubah penyerta mengandung data hilang. Proporsi dan polanya terlihat pada Gambar 4. PR dikeluarkan dari model karena memiliki terlalu banyak data hilang, yaitu lebih dari $70 \%$. Selanjutnya, data hilang pada peubah penyerta lainnya diimputasi menggunakan algoritma multivariate imputation by chained equations (MICE) (Van Buuren \& Oudshoorn 2011). Algoritma MICE digunakan dengan metode random forest (RF), 50 multi imputasi, dan 10 iterasi. 

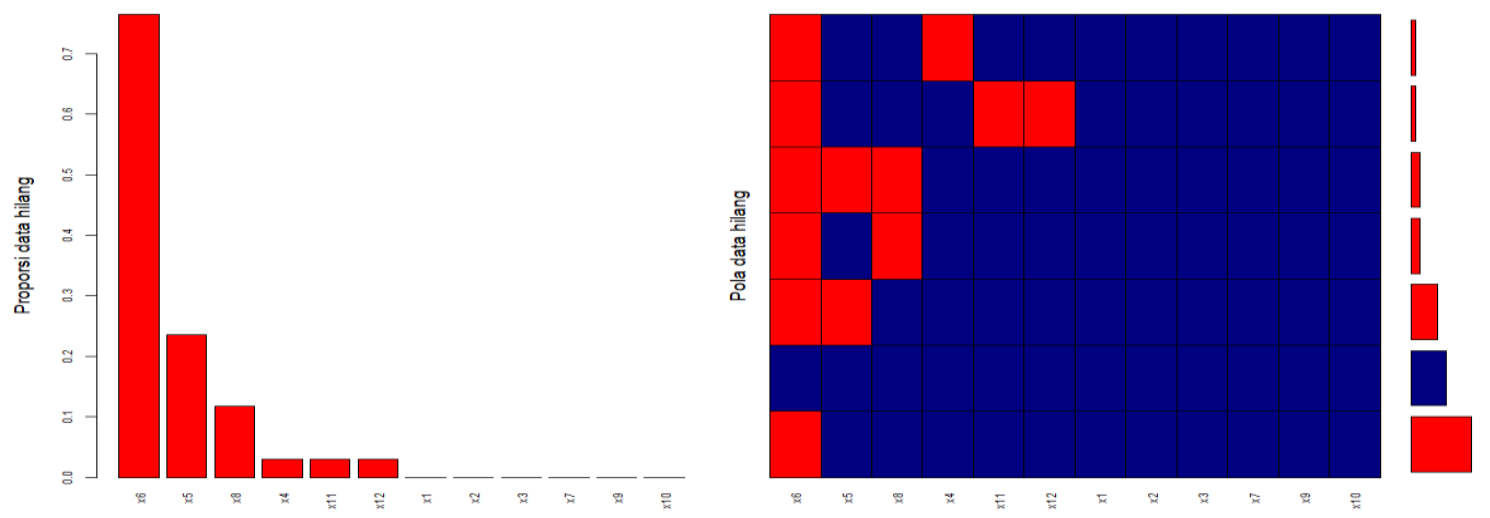

Gambar 4. Data hilang pada peubah penyerta.

Peubah penyerta yang sudah tidak lagi mengandung data hilang dicek korelasinya dengan peubah respon. Korelasi peubah penyerta dengan peubah respon pada Tabel 2. relatif kecil, baik pada peubah respon SRS maupun peubah respon WPS. Ini menunjukan bahwa pengaruh peubah penyerta yang tersedia terhadap penduga langsung IHK provinsi kurang kuat. Korelasi peubah penyerta dengan peubah respon WPS secara umum lebih tinggi dibanding peubah respon SRS. Korelasi peubah penyerta dengan peubah respon SRS lebih banyak bernilai positif, korelasi negatif terjadi pada PM, KUMKM, pertalite, PT, dan HJAUD. Sebaliknya, korelasi peubah penyerta dengan peubah respon WPS lebih banyak bernilai negatif, korelasi positif hanya terjadi pada HBUSD dan HJUSD.

Korelasi antar peubah penyerta juga ada yang relatif tinggi, ada indikasi multikolenieritas. Peubah penyerta yang terindikasi mengandung multikolinieritas tidak dapat ditentukan dengan jelas hanya dengan menggunakan korelasi. Nilai variance inflation factors (VIF) pada Tabel 2. dapat digunakan untuk mendeteksi indikasi ini dengan lebih teliti, hasilnya hanya nilai VIF pertalite dan PT yang relatif tinggi karena lebih besar dari 5 . Nilai VIF untuk dexlite tidak dapat ditentukan karena berkorelasi sangat tinggi dengan pertamax atau korelasinya bernilai satu.

Tabel 2. Nilai korelasi dan VIF peubah penyerta.

\begin{tabular}{lcccccccccccc}
\hline Peubah & \multicolumn{10}{c}{ Peubah Penyerta } \\
\cline { 2 - 12 } Respon & $x_{1}$ & $x_{2}$ & $x_{3}$ & $x_{4}$ & $x_{5}$ & $x_{7}$ & $x_{8}$ & $x_{9}$ & $x_{10}$ & $x_{11}$ & $x_{12}$ \\
\hline SRS & & & & & & & & & & & \\
$\quad$ Korelasi & -0.09 & -0.13 & 0.04 & -0.13 & -0.02 & 0.04 & 0.04 & 0.06 & 0.00 & 0.06 & -0.14 \\
$\quad$ VIF & 3.80 & 4.75 & 1.66 & 8.62 & 5.20 & - & 3.71 & 3.63 & 2.48 & 3.52 & 3.34 \\
WPS & & & & & & & & & & & \\
$\quad$ Korelasi & -0.04 & -0.06 & -0.01 & -0.23 & -0.06 & -0.01 & -0.26 & 0.10 & 0.07 & -0.09 & -0.06 \\
$\quad$ VIF & 3.80 & 4.75 & 1.66 & 8.62 & 5.20 & - & 3.71 & 3.63 & 2.48 & 3.52 & 3.34 \\
\hline
\end{tabular}

Pemilihan kombinasi peubah penyerta yang akan digunakan tidak cukup hanya dengan melihat nilai korelasi dan VIF-nya karena tidak dapat diketahui kombinasi mana yang paling baik. Oleh karena itu, peubah penyerta yang digunakan dipilih dengan regresi stepwise. Pemilihan ini dilakukan untuk memilih model terbaik, sehingga penggunaan peubah penyerta dapat lebih efektif. Model terbaik untuk respon SRS adalah model yang menggunakan tiga peubah penyerta pertalite, PT, dan PD dengan AIC sebesar 96.04. Sedangkan untuk respon WPS, model terbaiknya adalah model yang menggunakan peubah penyerta PD, HBUSD, HJUSD, HBAUD dan HJAUD dengan AIC sebesr 94.35.

\section{Penduga FH IHK Provinsi}

Pendugaan FH IHK provinsi dilakukan dengan menggunakan respon SRS (FH-SRS) dan menggunakan respon WPS (FH-WPS). Penduga FH-SRS lebih baik dari penduga lainnya karena nilai RRMSE-nya lebih kecil dari penduga lainnya. Ini diperlihatkan oleh Gambar 5. RRMSE penduga FHWPS relatif lebih teliti di area yang keragamannya tinggi dibandingkan penduga SRS, walapun secara umum tidak lebih baik. Ini terlihat dari nilai RRMSE penduganya. 


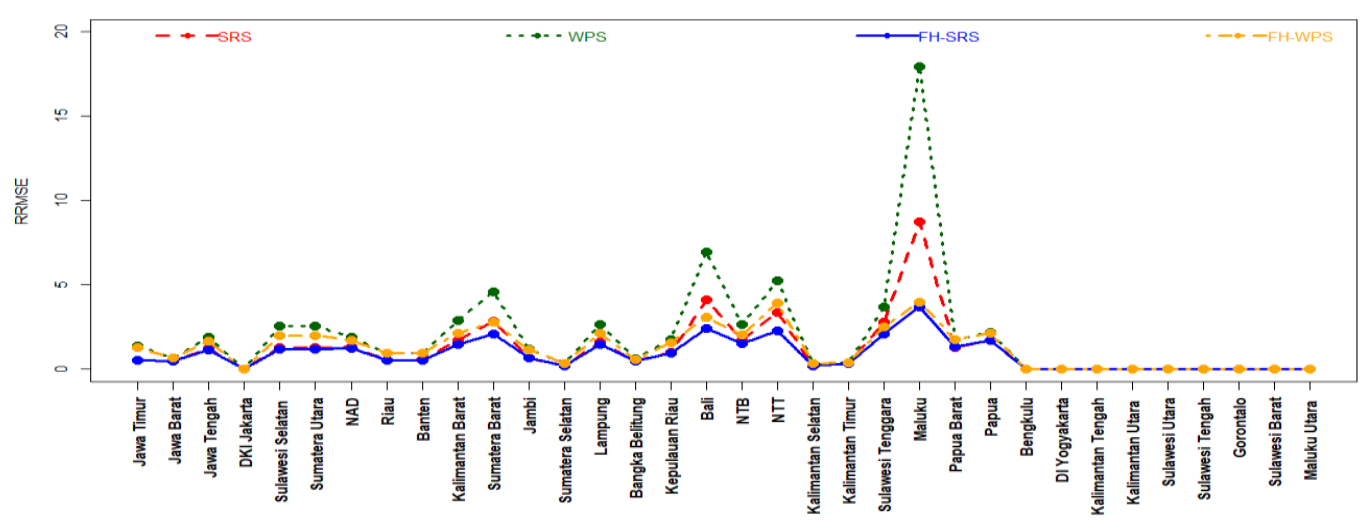

Gambar 4. Grafik RRMSE hasil pendugaan IHK provinsiJanuari 2018.

Tabel 3. Memperlihatkan ARRMSE dan rataan penduga IHK provinsi, serta penduga IHK nasional untuk setiap metode pendugaan. ARRMSE diperoleh dengan menghitung rataan dari RRMSE masingmasing penduga. Rataan penduga IHK provinsi diperoleh dengan menghitung rataan dari masingmasing penduga IHK provinsi. Sedangkan, pendugaa IHK nasional diperoleh dengan menggunakan rataan terboboti dari penduga IHK provinsi. Bobot masing-masing provinsi adalah rataan dari bobot kota contohnya. Kemudian, bobot ini dinormalkan sehingga totalnya sama dengan 100.

Penduga FH-SRS lebih baik dari penduga lainnya karena nilai ARRMSE-nya paling kecil pada Tabel 3., yaitu 0.85 dan penduga IHK nasionalnya dekat ke IHK nasional hasil dugaan BPS, walaupun penduga IHK nasional penduga FH-WPS lebih dekat ke IHK nasional hasil dugaan BPS. Namun, selisihnya tidak terlalu tinggi. Penduga FH-SRS meningkatkan ketelitian $26.25 \%$ lebih baik dari penduga langsung SRS, sedangkan penduga FH-WPS meningkatkan ketelitian $38.53 \%$ lebih baik dari penduga langsung WPS.

Tabel 3. Nilai ARRMSE dan rataan penduga IHK provinsi serta penduga IHK nasional.

\begin{tabular}{lccc}
\hline \multicolumn{1}{c}{ Metode } & ARRMSE & Rataan Penduga IHK Provinsi & Penduga IHK Nasional \\
\hline SRS & 1.16 & 132.75 & 133.19 \\
WPS & 1.98 & 132.47 & 133.09 \\
FH-SRS & 0.85 & 132.56 & 132.78 \\
FH-WPS & 1.22 & 132.40 & 132.77 \\
\hline Statistik IHK Nasional BPS & & 132.10 \\
\hline
\end{tabular}

\section{KESIMPULAN}

Pendugaan area kecil dilakukan untuk meningkatkan ketelitian hasil pendugan langsung. Pada penelitian ini, penduga FH secara umum lebih baik dari penduga langsung. Penduga FH-SRS memiliki hasil dugaan paling baik terlihat dari nilai ARRMSE-nya yang paling kecil. Penduga ini menggunakan penduga langsung SRS sebagai peubah respon sehingga tidak tergantung dengan bobot kota contoh IHK. Berbeda dengan penduga FH-WPS yang tergantung dengan bobot kota contoh IHK. Akan tetapi, harga di wilayah urban dan rural suatu kabupaten/kota diasumsikan relatif sama pada penelitian ini sehingga kajian lebih lanjut pendugaan tanpa asumsi ini perlu untuk dilakukan.

Penelitian lebih lanjut sedang dilakukan untuk mencari solusi untuk mengatasi provinsi yang hanya memiliki satu kota contoh. Ada sebanyak 9 provinsi yang hanya memiliki satu kota contoh sehingga penduga IHK-nya sama dengan IHK kota contoh yang ada. Kontribusi penduga FH pada provinsi tersebut tidak dapat dilihat karena MSE penduga langsungnya tidak dapat diduga.

Peubah penyerta yang digunakan juga menarik untuk dipelajari. Pada penelitian ini, peubah penyerta dipilih yang tersedia setiap bulan dan merupakan pencatatan administrasi, sehingga kemungkinan kesalahan pengukurannya kecil. Namun, peubah penyerta pada penelitian ini korelasinya relatif kecil terhadap peubah respon, sehingga perlu untuk dicari alternatif.

\section{UCAPAN TERIMA KASIH}


Ucapan terima kasih disampaikan penulis kepada BPS yang telah memberikan dana dan data untuk penelitian ini. Ucapan terima kasih juga penulis sampaikan kepada BI dan Pertamina yang telah menyediakan data peubah penyerta.

\section{DAFTAR PUSTAKA}

[BPS] Badan Pusat Statistik (ID). (2013). Pedoman Survei Harga Konsumen. Jakarta (ID): Badan Pusat Statistik.

[BPS] Badan Pusat Statistik (ID). (2018). Indeks Harga Konsumen 82 Kota di Indonesia [2012=100] 2018 Consumer Price Indeces of 82 Cities In Indonesia [2012=100] 2018. Jakarta (ID): Badan Pusat Staistik.

[ONS] Office for National Statistics (UK). (2010). Consumer Price Indices Technical Manual (2010 Editi). Newport (UK): Office of Public Sector Information (OPSI).

Bala, U., Chin, L. E. E., Kaliappan, S. R., \& Ismail, N. W. (2017). The Impacts of Oil Export and Food Production on Inflation in African OPEC Members. International Journal of Economics and Management, 11(S3), 573-590. Retrieved from http://www.econ.upm.edu.my/ijem

Dawber, J., Würz, N., \& Smith, P. (2019). The development of regional CPIH: assessment of small area estimation for regional expenditure weights. Second Report of Office for National Statistics. Newport (UK): Office for National Statistics.

Fay, R. E. ., \& Herriot, R. A. (1979). Estimates of Income for Small Places: An Application of James-Stein Procedures to Census Data. Journal of the American Statistical Association, 74:366a, 269-277. Retrieved from http://dx.doi.org/10.1080/01621459.1979.10482505\%0APLEASE

Islam, R., Bashawir, A., Ghani, A., Mahyudin, E., \& Manickam, N. (2017). Determinants of Factors that Affecting Inflation in Malaysia. International Journal of Economics and Financial Issues, 72), 355-364.

Kalalo, H. Y. T., Rotinsulu, T. O., \& Maramis, M. T. B. (2016). Analisis Faktor-Faktor yang Mempengaruhi Inflasi. Jurnal Berkala IImiah Efisiensi, 16(01), 706-717.

Lim, Y. C., \& Sek, S. K. (2015). An Examination on the Determinants of Inflation. Journal of Economics, Business and Management, 3(7), 678-682. https://doi.org/10.7763/JOEBM.2015.V3.265

Nuryadin, H., Susetyo, B., \& Sadik, K. (2017). Application of Small Area Estimation of Multivariate Fay-Herriot Model (Mfh) for The Average of Per Capita Expenditure in Village Level. International Journal of Scientific \& Engineering Research, 8(10), 1673-1676.

Pusponegoro, N. H., \& Rachmawati, N. (2018). Spatial Empirical Best Linear Unbiased Prediction in Small Area Spatial Empirical Best Linear Unbiased Prediction in Small Area Estimation of Poverty Estimation of Poverty. Procedia Computer Science, 135, 712-718. https://doi.org/10.1016/j.procs.2018.08.214

Rao, J. N. K., \& Molina, I. (2015). Small area estimation. New Jersey (USA): John Wiley and Sons, Inc.

Saputra, K., \& Nugroho, S. (2014). Analisis Faktor-Faktor yang Mempengaruhi Inflasi. Diponegoro Journal of Economics, 3(1), 1-15.

Shang, Y., Zhu, C., \& Li, S. (2018). Estimation and Explanation of Time-Varying Weights in Chinese CPI Estimation and Explanation of Time-Varying Weights in Chinese CPI. Emerging Markets Finance and Trade, 54(15), 3426-3437. https://doi.org/10.1080/1540496X.2018.1485095

Sriliana, I., Sunandi, E., \& Rafflesia, U. (2017). Pemodelan Kemiskinan di Provinsi Bengkulu Menggunakan Small Area Estimation. Jurnal MIPA, 4O(2), 134-140.

Sundara, V. Y., Kurnia, A., \& Sadik, K. (2017). Clustering Information of Non-Sampled Area in Small Area Estimation of Poverty Indicators Clustering Information of Non-Sampled Area in Small Area Estimation of Poverty Indicators. In IOP Conf. Series: Earth and Environmental Science 58 (2017) 012020 (pp. 1-8). https://doi.org/doi:10.1088/1755-1315/58/1/012020

Ubaidillah, A., Notodiputro, K. A., Kurnia, A., \& Wayan, I. (2019). Multivariate Fay-Herriot models for small area estimation with application to household consumption per capita expenditure in Indonesia. Journal of Applied Statistics, O(0), 1-17. https://doi.org/10.1080/02664763.2019.1615420

Van Buuren, S., \& Oudshoorn, K. G. (2011). mice : Multivariate Imputation by Chained. Journal of Statistical Software, 45(3), 1-67.

Würz, N., Schmid, T., Smith, P., \& Tzavidis, N. (2017). Construction of Regional Consumer Price Indices using Small Area Estimation. In Statistische Woche: 2017, Rostock, Germany. 19 Sep 2017 - 22 Feb 2018. Retrieved from https://eprints.soton.ac.uk/417644/1/W_rz_et_al._2017_rCPI_poster.pdf

Yoshizaki, Y., \& Haomori, S. (2014). The effects of oil price shocks on expenditure category CPI. Applied Economics, 46(14), 1652-1664. https://doi.org/10.1080/00036846.2014.881977 